\title{
PENGARUH SUBSTITUSI TEPUNG DAUN SINGKONG (Manihot Utilisima) YANG DIFERMENTASI MENGGUNAKAN Rhizopus sp. PADA PAKAN TERHADAP PERTUMBUHAN DAN KELANGSUNGAN HIDUP BENIH IKAN MAS (Cyprinus carpio)
}

\author{
EFFECT SUBSTITUTION OF CASSAVA LEAF MEAL (Manihot Utilisima) \\ FERMENTATION Rhizopus sp. ON FEED TO GROWTH AND SURVIVAL RATE Cyprinus \\ carpio SEEDS
}

\author{
Sri Rahmadani, Dewi Nur'aeni Setyowati, Dewi Putri Lestari ${ }^{*}$ \\ ${ }^{1)}$ Program Studi BudidayaPerairan Fakultas Pertanian Universitas Mataram \\ *)alamat korespondensi : srirahmadani080@gmail.com
}

\begin{abstract}
Abstrak
Penelitian ini bertujuan untuk untuk mengetahui pertumbuhan dan kelangsungan hidup benih ikan mas (Cyprinus carpio) yang diberi pakan tepung daun singkong fermentasi menggunakan Rhizopus sp. Metode yang digunakan dalam penelitian ini adalah metode eksperimental menggunakan Rancangan Acak Lengkap (RAL) yang terdiri dari 5 perlakuan an 3 kali ulangan sehingga diperoleh 15 unit percobaan, yakni P0 (tanpa penambahan tepung daun singkong fermentasi), P1 (penambahan tepung daun singkong fermentasi 10\%), P2 (penambahan tepung daun singkong fermentasi 15\%), P3 (penambahan tepung daun singkong fermentasi 20\%), P4 (penambahan tepung daun singkong fermentasi 25\%). Hasil penelitian menunjukkan bahwa tidak adanya pengaruh yang nyata terhadap pertumbuhan mutlak, laju pertumbuhan harian, Rasio Konversi Pakan (FCR), dan Kelangsungan Hidup ikan mas. Diketahui bahwa P1 (penambahan tepung daun singkong fermentasi 10\%) merupakan perlakuan terbaik pada semua parameter uji. Sedangkan untuk kelangsungan hidup P3 (penambahan tepung daun singkong fermentasi 20\%) dan P4 (penambahan tepung daun singkong fermentasi 25\%) merupakan perlakuan terbaik untuk kelangsungan hidup yaitu $100 \%$.
\end{abstract}

Kata kunci : Pertumbuhan, Kelangsungan Hidup, Pakan, Daun Singkong.

\begin{abstract}
This study aims to determine the growth and survival rate Cyprinus carpio seeds fed fermented cassava leaf flour using Rhizopus sp. The method used in this study was an experimental method using a Completely Randomized Design (CRD) consisting of 5 treatments and 3 replications to obtain 15 experimental units, namely P0 (without the addition of fermented cassava leaf meal), P1 (addition of 10\% fermented cassava leaf meal), P2 (addition of 15\% fermented cassava leaf meal), P3 (addition of 20\% fermented cassava leaf meal), and P4 (addition of 25\% fermented cassava leaf meal. The results showed that there was no significant effect on absolute growth, daily growth rate, Feed Conversion Ratio (FCR), and Survival rate of carp. It is known that P1 (addition of $10 \%$ fermented cassava leaf meal) is the best treatment for all test parameters.
\end{abstract}


As for the survival rate of P3 (addition of 20\% fermented cassava leaf meal) and P4 (addition of $25 \%$ fermented cassava leaf meal) is the best treatment for survival that is $100 \%$.

Key Word : Growth, Survival Rate, Feed, Cassava Leaf

\section{PENDAHULUAN}

Pakan merupakan salah satu faktor yang menentukan keberhasilan usaha budidaya. Pada umumnya pakan komersial dapat menghabiskan sekitar 60-70\% dari total biaya produksi (Hadadi et al. 2009). Tingginya harga pakan dan kualitas nutrisinya yang rendah merupakan hambatan dalam proses budidaya. Oleh karena itu, dibutuhkan bahan yang dapat menekan biaya produksi tetapi tidak menurunkan kandungan nutrien dari pakan (Danu et al.2015).

Kegiatan usaha budidaya perikanan tidak terlepas dari kebutuhan pakan. Mahalnya harga pakan ikan tidak terlepas dari harga bahan pembuat pakan yang ada. Salah satu cara untuk menekan biaya produksi adalah memanfaatkan sumber bahan baku yang melimpah, murah dan masih memiliki nilai gizi yang cukup. Hijauan dalam bentuk basah maupun tepung merupakan salah satu sumber protein yang murah yang dapat digunakan untuk mengurangi penggunaan tepung ikan. Bahan pakan lokal yang belum akrab di kalangan para pembudidaya ikan dapat digunakan untuk menyusun pakan ikan seperti bungkil biji karet, daun singkong, daun pisang, dan kangkung.Beberapa penelitian telah dilakukan untuk mengeksplor sumber bahan baku nabati antara lain tepung daun singkong (Yosif et al., 1994 dalam Adewulu, 2008).

Daun singkong merupakan salah satu bahan pakan alternatif yang dapat dijadikan bahan pakan ikan.Daun singkong juga memiliki kandungan nutrisi baik yaitu memiliki protein tinggi berkisar antara 23,42 $\%$, serat kasar $15,80 \%$, lemak 6,31 \% (Tenti, 2006 dalam Danu et al.2015). Penggunaan Rhizopus sp. sebagai bahan fermentasi dilakukan untuk meningkatkan nilai nutrisi pakan dan mengurangi kandungan $\mathrm{HCN}$ yang terkandung dalam daun singkong (Endrawati et al. 2017). Dalam rangka memanfaatkan bahan pakan lokal pada penelitian ini memanfaatkan pakan yang disubstitusi tepung daun singkong yang difermentasi Rhizopus sp. untuk mengetahui pertumbuhan dan kelangsungan hidup dari benih ikan mas. Tujuan dari penelitian ini adalah untuk mengetahui pertumbuhan dan kelangsungan hidup benih ikan mas yang diberi pakan yang disubstitusi tepung daun singkong fermentasi menggunakan Rhizopus sp..

\section{METODE PENELITIAN Waktu dan Tempat}

Penelitian ini dilaksanakan pada bulan Maret - April 2019 di Laboratorium Budidaya Program Studi Budidaya Perairan, Universitas Mataram.

\section{Rancangan Percobaan}

Penelitian ini menggunakan

Rancangan Acak Lengkap (RAL). Perlakuan yang diuji yaitu:

P0: Tanpa ditambahkan tepung daun singkong

P1: Pakan yang ditambahkan fermentasi tepung daun singkong $10 \%$

P2: Pakan yang ditambahkan fermentasi tepung daun singkong $15 \%$

P3: Pakan yang ditambahkan fermentasi tepung daun singkong $20 \%$

P4: Pakan yang ditambahkan fermentasi tepung daun singkong $25 \%$

\section{Prosedur Penelitian \\ Persiapan}

Wadah yang digunakan pada penelitian ini yaitu akuarium ukuran

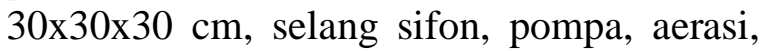


timbangan, $\mathrm{pH}$ meter, DO meter, serok, blender, ayakan, alat tulis, kamera. Bahan yang digunakan yaitu air tawar, bibit ikan mas $\pm 10 \mathrm{gr}$, tepung daun singkong yang difermentasi menggunakan Rhizopus sp. tepung ikan, tepung jagung dan tepung tapioka.

Daun singkong yang digunakan pada bagian daun yang yang hijau tua, kemudian dicuci bersih untuk menghilangkan kotoran. Selanjutnya daun singkong dipotong kecilkecil dan dikeringkan. Daun singkong dijemur dibawah sinar matahari selama 2-3 hari (sampai kering). Setelah kering, daun singkong dihaluskan menggunakan blender hingga menjadi tepung dan diayak (pemblenderan dilakukan sesaat daun singkong baru saja selesai dijemur). Tepung daun singkong kemudian ditimbang sesuai dengan jumlah yang diperlukan. Setelah ditimbang, tepung daun singkong kemudian dikukus selama 45 menit untuk proses penghilangan HCN. Tepung daun singkong yang telah dikukus dibiarkan sampai dingin, kemudian difermentasi dengan menggunakan Rhizopus sp. sebanyak 2\% dari berat biomassa (Danu et al. 2015). Setelah bahan diberi Rhizopus sp. diaduk rata, kemudian dibungkus dengan plastik. Plastik dilubangi kecil-kecil dibeberapa bagian untuk mendapatkan kondisi anerob. Proses fermentasi tepung daun singkong berlangsung selama 72 jam (3 hari). Setelah proses fermentasi daun singkong berhasil, fermentasi daun singkong tersebut dikeringkan kemudian dihaluskan menjadi tepung dan siap diformulasikan ke dalam pakan.Ciri-ciritepung daun singkong yang sudah difermentasi yaitu sudah ditumbuhi jamur berwarna abu-abu dan baunya sedikit pesing (Danu et al., 2015).

Proses pembuatan pakan dilakukan dengan menimbang bahan satu persatu pakan mulai dari bahan yang terkecil hingga bahan yang paling banyak dibutuhkan. Kemudian dicampur sampai rata dan ditambahkan sedikit air agar campuran bahan dapat dibentuk. Setelah dibentuk bulat-bulat, pakan kemudian digiling menggunakan penggilingan pakan agar terbentuk pakan ikan seperti pakan pada umumnya. Kemudian pakan yang terbentuk dijemur dibawah sinar matahari selama 1-2 hari (sampai kering) dan siap diberikan kepada ikan.

Kepadatan benih yang digunakan yaitu 10 ekor pada setiap akuarium. Sebelum ditebar, benih terlebih dahulu ditimbang beratnya sebagai data berat awal. Pemberian pakan dilakukan setiap hari dengan frekuensi 3 kali sehari yaitu pada pukul 09.00, 13.00, dan 17.00 sebanyak 5\% dari biomassa tubuh ikan.

Pengamatan parameter utama terhadap pertumbuhan dan kelangsungan hidup benih ikan nila dilakukan dengan cara mengetahui tingkat pertumbuhan berat badan benih ikan dengan perlakuan pemberian pakan yang telah dilakukan pada benih ikan mas dengan lama pemeliharaan 35hari. Penimbangan ikan setiap 7 hari sekali selama masa pemeliharaan berlangsung. Parameter kualitas air yang diukur yaitu suhu, $\mathrm{pH}$ dan DO. Pengukuran parameter pemeliharaan benih ikan mas dilakukan pada awal penebaran. Suhu diukur dengan termometer, $\mathrm{pH}$ diukur dengan $\mathrm{pH}$ meter dan $\mathrm{DO}$ diukur dengan DO meter.

\section{Parameter Uji \\ Pertumbuhan Mutlak}

Pertumbuhan Mutlak dihitung berdasarkan rumus (Sitaniapessy, 2016):

$$
\Delta \mathrm{W}=\mathrm{Wt}-\mathrm{Wo}
$$

Keterangan :

$\Delta \mathrm{W}=$ Pertumbuhan mutlak $(\mathrm{g})$;

$\mathrm{Wt}=$ Berat rata-rata akhir $(\mathrm{g})$;

Wo = Berat rata-rata awal $(\mathrm{g})$;

\section{Laju Pertumbuhan (SGR)}

Specific Growth Rate Effendie (1979) dalam Agustin et al. (2014):

$$
(\mathrm{SGR})=((\ln \mathrm{Wt}-\ln \mathrm{Wo}) / \mathrm{t}) \times 100 \%)
$$


Keterangan :

SGR = Laju Pertumbuhan Harian (\%);

$\mathrm{Wt}=$ Bobot ikan di akhir pemeliharaan $(\mathrm{g})$;

$\mathrm{Wo}=$ Bobot ikan di awal pemeliharaan $(\mathrm{g})$;

$\mathrm{t}=$ Lama waktu pemeliharaan (hari);

\section{Rasio Konversi Pakan (FCR)}

Rasio konversi apakan dihitung dengan rumus :

$$
\mathrm{FCR}=(\Sigma \mathrm{f} * \mathrm{Bkf}) /(\mathrm{Wt}-\mathrm{Wo}) ;
$$

Keterangan :

FCR = Rasio Konversi Pakan;

$\sum \mathrm{F}=$ Rata-rata jumlah pakan yang diberikan (gram);

$\Sigma$ Bkf $=$ Berat kering pakan (gram);

$\mathrm{Wt}=$ Berat rata-rata individu pada akhir penelitian (gram);

$\mathrm{Wo}=$ Berat rata-rata individu pada awal penelitian (gram);

\section{Kelangsungan Hidup (Survival Rate)}

Kelangsungan hidup dihitung dengan rumus :

$$
\mathrm{SR}(\%)=(\mathrm{Nt} / \mathrm{No}) \times 100 \% \text {; }
$$

Keterangan :

SR = Tingkat Kelangsungan Hidup;

$\mathrm{Nt}=$ Jumlah ikan yang hidup pada akhir penelitian ;

No= Jumlah ikan yang hidup pada awal penelitian.

\section{Analisis Data}

Analisis data yang digunakan dalam penelitian ini yaitu Analisys of Variance (ANOVA) signifikansi 5\% $(0,05)$.

\section{HASIL}

\section{Pertumbuhan Mutlak}

Penambahan tepung daun singkong yang difermentasi menggunakan Rhizopus sp. pada pakan dengan dosis yang berbeda pada setiap perlakuan tidak memberikan pengaruh yang berbeda nyata $(\mathrm{P}>0.05)$ terhadap pertumbuhan berat mutlak ikan mas. Hasilnya dapat dilihat pada Gambar 1.

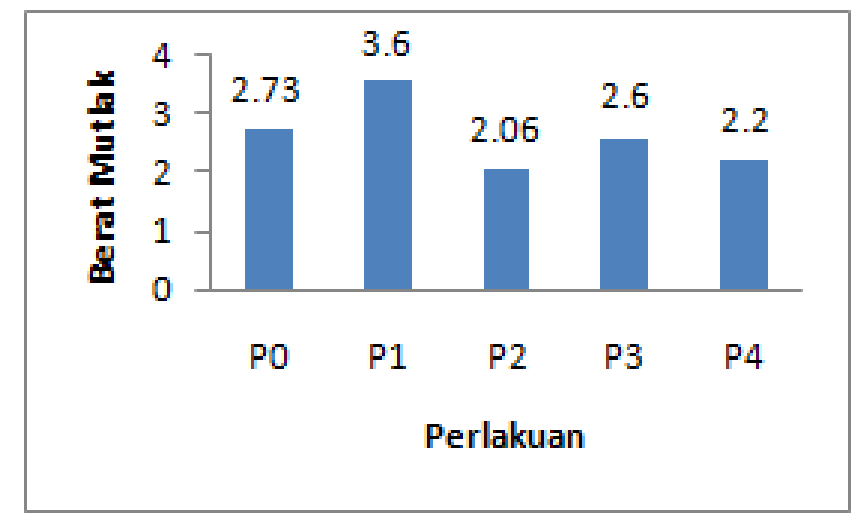

Gambar 1. Pertumbuhan berat mutlak

\section{Laju Pertumbuhan Harian (SGR)}

Substitusi tepung daun singkong yang difermentasi menggunakan Rhizopus sp. pada pakan dengan dosis yang berbeda pada setiap perlakuan tidak memberikan pengaruh yang berbeda nyata $(\mathrm{P}>0.05)$ terhadap laju petumbuhan harian ikan mas. Hasilnya dapat dilihat pada Gambar 2.

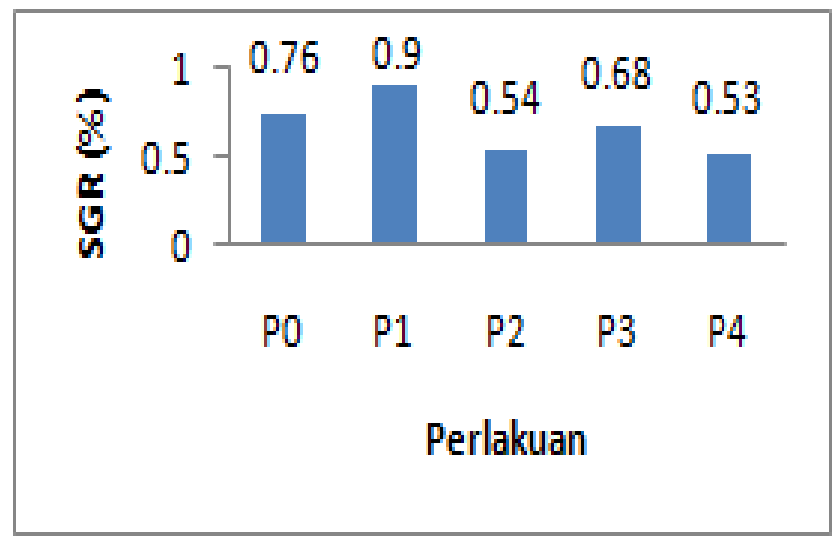

Gambar2. Laju pertumbuhan harian

\section{Rasio Konversi Pakan (FCR)}

Substitusi tepung daun singkong yang difermentasi menggunakan Rhizopus sp. pada pakan dengan dosis yang berbeda pada setiap perlakuan tidak memberikan pengaruh yang berbeda nyata $(\mathrm{P}>0.05)$ terhadap rasio konversi pakan ikan mas. Hasil perhitungan rasio konversi pakan pada perlakuan P0 nilainya 1,86 , perlakuan $\mathrm{P} 1$ nilainya 1,44 , 
perlakuan P2 nilainya 3,03, perlakuan P3 nilainya 2,06, dan perlakuan $\mathrm{P} 4$ nilainya 3,23. Hasilnya dapat dilihat pada Gambar 3.

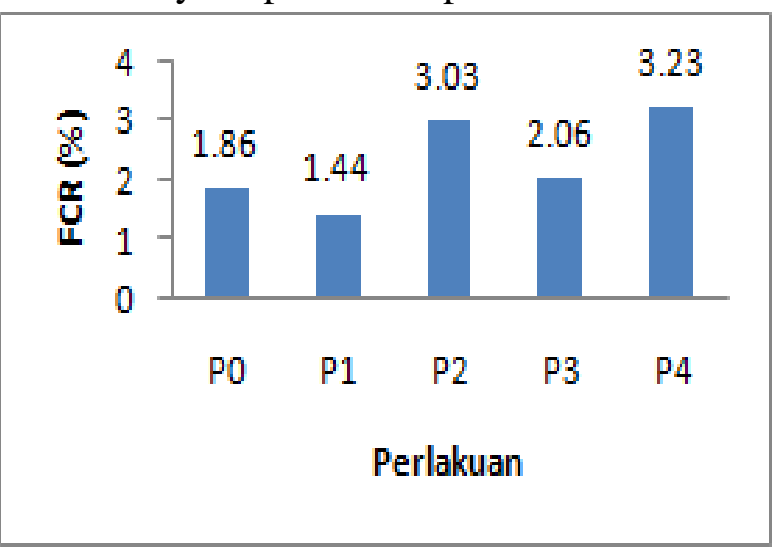

Gambar 3. Rasio Konversi Pakan (FCR)

\section{Kelangsungan Hidup (SR)}

Substitusi tepung daun singkong yang difermentasi menggunakan Rhizopus sp. pada pakan dengan dosis yang berbeda pada setiap perlakuan tidak memberikan pengaruh yang berbeda nyata $(\mathrm{P}>0.05)$ terhadap kelangsungan hidup ikan mas. Hasilnya dapat dilihat pada Gambar 4.

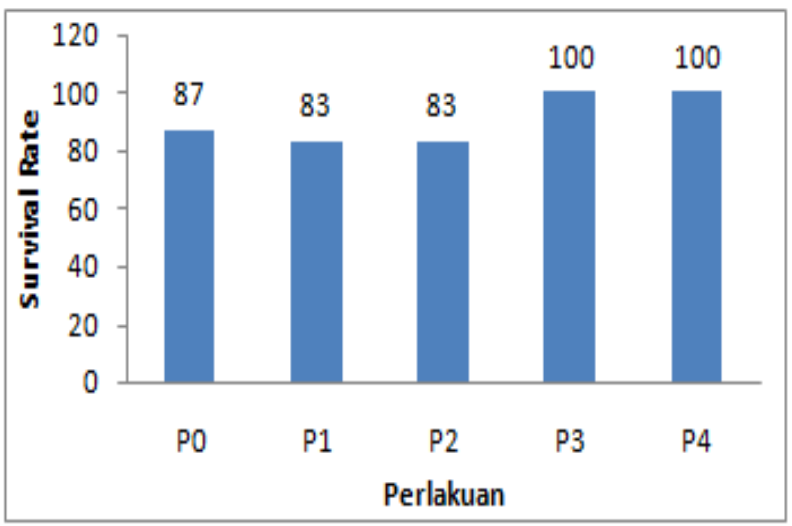

Gambar 4. Kelangsungan hidup (SR)

\section{PEMBAHASAN}

Pada penelitian ini pemberian pakan ikan mas yang disubstitusi tepung daun singkong yang difermentasi menggunakan Rhizopus sp. tidak memberikan pengaruh yang berbeda nyata terhadap pertumbuhan berat mutlak, laju pertumbuhan harian, rasio konversi pakan, dan kelangsungan hidup ikan mas.

Pada hasil pertumbuhan mutlak penggunaan tepung daun singkong fermentasi pada pakan dapat menggantikan tepung ikan dan tepung jagung. Pada P1 tepung ikan yang disubtitusi oleh tepung daun singkong fermentasi sebanyak 3\% dan tepung jagung sebanyak 7\%. Pada penelitian ini penggunaan tepung ikan berkisar antara 32$42 \%$, tepung jagung $39-53 \%$ dan tepung daun singkong fermentasi 0-25\%. Dari hasil subtitusi tepung daun singkong fermentasi pada P1 menghasilkan pertumbuhan mutlak sebesar 3,09 gram.

Sama halnya dengan laju pertumbuhan mutlak, laju pertumbuhan harian juga menunjukkan hasil yang tidak berbeda nyata. Hal ini diduga karena kandungan serat kasar yang terlalu tinggi. Penambahan tepung daun singkong $10 \%$ dalam pakan untuk menggantikan tepung ikan dan tepung jagung adalah komposisi yang sesuai untuk bahan campuran pakan pakan setelah dilihat dari hasil pertumbuhan hariannya. Hal ini sesuai dengan penelitian Danu (2015) bahwa pemberian daun singkong fermentasi $10 \%$ di dalam pakan mempunyai nilai laju pertumbuhan yang paling tinggi yaitu 2,24\%. Pada penelitian ini subtitusi tepung daun singkong fermentasi pada perlakuan P1 untuk tepung ikan $3 \%$ dan tepung jagung $7 \%$, ini merupakan komposisi yang baik untuk pakan ikan mas dilihat dari laju pertumbuhan hariannya selama 35 hari pemeliharaan. Pakan perlakuan P1 memiliki nilai serat kasar yang rendah yaitu $7,5 \%$. Hal ini membuat ikan mas mudah mencerna pakan yang diberikan dan dimanfaatkan untuk petumbuhan. Semakin rendah kandungan serat kasar maka semakin baik untuk kebutuhan pakan ikan. Kandungan serat kasar yang dianjurkan dalam pakan ikan adalah 35\% (Iskandar, 2011 dalam Kardana et al., 2012). Kandungan serat kasar 8-12\% dalam pakan masih dapat ditolerir oleh ikan pada 
umumnya, namun kandungan serat yang lebih tinggi menyebabkan penurunan pertumbuhan (Iskandar, 2011 dalam Kardana et al., 2012). Untuk ikan omnivora, batas maksimal kandungan serat kasar pada pakan ikan yaitu 3\% (Tacon, 1986 dalam Haetami et al., 2000).

Data nilai FCR diperoleh dengan membandingkan jumlah pakan yang diberikan selama pemeliharaan dengan berat ikan pada setiap perlakuan. Rata-rata nilai FCR perlakuan P1 yaitu sebesar 1,44, diikuti oleh perlakuan P0 1,86, perlakuan P3 yaitu sebesar 2,06, perlakuan P2 sebesar 3,03 dan yang terakhir adalah perlakuan P4 sebesar 3,23. Menurut Djangkaru (1991) dalam Widyastuti et al., 2010 menyatakan semakin kecil nilai FCR berarti pakan semakin berkualitas, hal ini menunjukkan bahwa jumlah pakan yang dikonsumsi lebih besar daripada jumlah pakan yang tersisa. Nilai FCR masih dianggap efisien apabila kurang dari 3. Nilai FCR dari hasil penelitian ini tergantung dari pakan yang konsumsi oleh ikan mas. Semakin bagus kandungan pakan yang dikonsumsi ikan maka semakin bagus hasil FCRnya. FCR dalam penelitian ini bekisar antara 1,44-3,23. Pada Perlakuan P2 dan P4 memiliki nilai FCR diatas 3 sehingga masih tidak efisien dibandingkan Perlakuan P1, P3 dan P0 yang nilai FCRnya kurang dari 3. Pakan Perlakuan P1 memiliki nilai FCR 1,44, Perlakuan P0 1,86 dan perlakuan P3 2,06. Sehingga pakan yang FCRnya kurang dari 3 cocok untuk pakan ikan mas. Sutriana (2005) mengatakan bahwa FCR dari pakan ikan Lele yang menggunakan tepung daun singkong sebagai pengganti tepung kedelai memiliki nilai FCR 1,74-4,68.

Penambahan tepung daun singkong pada pakan tidak mempengaruhi secara nyata terhadap tingkat kelangsungan hidup ikan mas. Pada Gambar 4. menunjukkan bahwa angka kelangsungan hidup pada perlakuan P3 dan P4 yaitu $100 \%$, pada perlakuan P0 yaitu $86 \%$ serta P1 dan P2 yaitu $83,3 \%$.
Selama penelitian dapat dilihat bahwa kelangsungan hidup ikan mas tidak selamanya dipengaruhi oleh faktor pakan, melainkan dipengaruhi oleh faktor lain seperti penanganan selama pemeliharaan dan berbedanya kemampuan ikan dalam menyerap makanan yang diberikan. Tingkat kelangsungan hidup pada ikan banyak dipengaruhi oleh faktor lingkungan, misalnya penanganan dan kualitas air. Penanganan yang salah dapat menyebabkan ikan stres, sehingga kondisi kesehatan ikan menurun dan dapat menyebabkan kematian (Mustofa et al., 2018).

\section{KESIMPULAN}

Berdasarkan hasil penelitian disimpulkan bahwa substitusi tepung daun singkong yang difermentasi menggunakan Rhizopus sp. pada pakan perlakuan P1 memberikan pertumbuhan berat mutlak sebesar 3,6 gram, pertumbuhan harian sebesar $0,9 \%$, FCR sebesar 1,44 cenderung lebih baik daripada perlakuan yang lain. Sedangkan untuk kelangsungan hidup $100 \%$ yaitu pada perlakuan P3 dan P4 dengan dosis penambahan tepung daun singkong $20 \%$ dan $25 \%$.

\section{DAFTAR PUSTAKA}

Adewulu, M.A. 2008. Potentials of Sweet Potato (Ipomea batatas) Leaf Meal as Dietary Ingredient for Tilapia zilli Fingerlings.Berkala Perikanan Terubuk, 42 (2).

Agustin., Ade Dwi S., Yulisman. 2014. Konversi Pakan, Laju Pertumbuhan, Kelangsungan Hidup dan Populasi Bakteri Benih Ikan Gabus (Channa striata) yang Diberi Pakan dengan Penambahan Probiotik. Jurnal Akuakultur Rawa Indonesia, 2(1) :5566. 
Danu, Rahmad., Adelina dan Benny H. 2015. Pemanfaatan Fermentasi Daun Singkong (Manihot utilisima) dalam Pakan Buatan terhadap Pertumbuhan dan Kelulushidupan Benih Ikan Gurami (Osphronemus gouramy Lac.). Jurnal : 12-hal.

Endrawati, Dwi dan E. Kusumaningtyas. 2017. Several Functions of Rhizopus sp. on Increasing Nutritional Value of Feed Ingredient. Jurnal Wartazoa 27 (2): 081-088.

Hadadi, A., Herry, K. T. Wibowo, E. Pramono, A. Surahman, dan E. Ridwan. 2009. Aplikasi Pemberian Maggot sebagai Sumber Protein dalam Pakan Ikan Lele Sangkuriang (Clarias sp.) dan Gurame (Osphronemus gouramy Lac.).Balai Pusat Budidaya Air Tawar Sukabumi :175 - 181.

Haetami, Kiki., Rita Rostika., Junianto. 2000. Pengaruh Berbagai Imbangan EnergiProtein Ransum Silase Ikan Terhadap Efisiensi Pakan pada Ikan Jambal Siam (Pangasius hypophtalmus SAUVAGE). Jurnal Bionatura, 2 (3) : 136-143.

Kardana, Danu., Kiki H., Ujang S.. 2012. Efektivitas Penambahan Tepung Magot dalam Pakan Komersil terhadap pertumbuhan Benih Ikan Bawal Air Tawar (Colossoma macropomum).Jurnal Perikanan dan Kelautan. 3 (4) : 177-184.

Mustofa, Arifin., Sri Hastuti., Diana R. 2018. Pengaruh Periode Pemuasaan terhadap Efisiensi Pemanfaatan Pakan, Pertumbuhan dan Kelulushidupan Ikan Mas (Cyprinus carpio).Journal of Aquaculture Management And Technology 7 (1) : 18-27.

Sitaniapessy, Jolanda. 2016. Pemberian Pakan Pelet dan Bahan Baku Lokal terhadap Pertumbuhan Ikan Nila (Oreochromis niloticus).The Journal of Fisheries Development, 3(1): 11-16.

Sutriana., A, 2005. The Use of Caassava As A Dietary Component for African Catfish Fry. Jurnal Kedokteran Hewan Vol.1 (2).

Widyastuti, Sukanto, Rukaya. 2010. Penggunaan Pakan Fermentasi pada Budidaya Ikan Sistem Keramba Jaring Apung untuk Mengurangi Potensi Eutrofikasi Di Waduk Wadaslintang.Limnotek 17 (2) : 191200. 